\title{
POLA MAKAN DAN KEJADIAN ANEMIA PADA MAHASISWI YANG TINGGAL DI KOS-KOSAN
}

\author{
Eating Pattern and Anemia Events in Students Staying in Boarding House \\ Ayu Dwi Putri Rusman \\ ${ }^{1}$ Fakultas Ilmu Kesehatan Universitas Muhammadiyah Parepare \\ (ayudwiputri88@yahoo.co.id)
}

\begin{abstract}
ABSTRAK
Pola makan merupakan perilaku penting yang dapat mempengaruhi keadaaan gizi seseorang. Pola makan mahasiswi yang tinggal di kos-kosan terkadar tidak diperhatikan, sehingga tidak sedikit yang mengalami gangguan kesehatan, salah satunya adalah anemia. Tujuan penelitian ini menganalisis pengaruh pola makan terhadap kejadian anemia pada mahasiswi yang tinggal di kos-kosan. Subjek yang digunakan adalah mahasiswi Fakultas Ilmu Kesehatan, Universitas Muhammadiyah Parepare dengan jumlah sampel sebanyak 100 orang. Penelitian ini menggunakan metode penelitian kuantitatif dengan rancangan cross sectional study. Variabel pada penelitian ini adalah umur, pola makan dan status anemia. Metode analisis yang digunakan adalah analisis deskriptif untuk univaribel, analisis uji chi square untuk bivariabel dengan tingkat kemaknaan $p<0,05$. Hasil penelitian menunjukkan bahwa dari 100 orang responden, ada sebanyak 42 orang yang berumur 19 tahun. Untuk variabel pola makan yang diukur berdasarkan angka kecukupan gizi (AKG) sebanyak 83 orang yang sudah mencukupi. Setelah dilakukan pemeriksaan kadar hemoglobin diketahui sebanyak 39 orang yang mengalami anemia dan 61 orang yang tidak mengalami anemia. Hasil uji chi-square diperoleh nilai OR sebesar 1,206 dengan nilai $p$ value sebesar 0,018. Hasil ini disimpulkan bahwa ada pengaruh pola makan dengan kejadian anemia dan mahasiswi yang mempunyai pola makan tidak cukup cenderung 1,206 kali lebih besar mengalami anemia dibandingkan mahasiswi yang mempunyai pola makan cukup. Hasil penelitian ini merekomendasikan untuk meningkatkan asupan makanan yang mengandung protein dan mengurangi mengkonsumsi teh kemasan.
\end{abstract}

Kata kunci : Mahasiswi, pola makan dan anemia

\section{ABSTRACT}

Diet is an important behavior that can affect one's nutritional state. The diet of female students living in boarding-lodging is unnoticed, so not a few have health problems, one of which is anemia. The purpose of this study to analyze the effect of diet on the incidence of anemia in female students living in boarding house. The subjects used are female students of the Faculty of Health Sciences, Muhammadiyah University of Parepare with a sample of 100 people. This research uses quantitative research method with cross sectional study design. The variables in this study were age, diet and anemia status. The analysis method used is descriptive analysis for univaribel, chi square test analysis for bivariable with significance level $p<0,05$. The results showed that of 100 respondents, there were as many as 42 people aged 19 years. For dietary variables measured based on nutritional sufficiency $(A K G)$ as many as 83 people who are sufficient. After examination of hemoglobin levels known as many as 39 people who have anemia and 61 people who do not have anemia. Chi-square test results obtained by OR value of 1.206 with a value of $p$ value of 0.018 . These results concluded that there is an effect of diet with the incidence of anemia and female students who have not enough diet tends to 1.206 times greater anemia than college students who have adequate diet. The results of this study recommend to increase the intake of foods containing protein and reduce the consumption of packaged tea

Keywords: Student, dietary habit and Anemi 


\section{PENDAHULUAN}

Pola makan merupakan perilaku paling penting yang dapat mempengaruhi keadaan gizi. Hal ini disebabkan karena kualitas dan kuantitas makanan dan minuman yang dikonsumsi akan mempengaruhi tingkat kesehatan individu dan masyarakat. Setiap individu membutuhkan pola makan yang sehat dan seimbang untuk menjaga kesehatan serta untuk mendukung kelancaran aktivitas, terutama bagi individu yang memiliki aktivitas keseharian yang padat, misalnya mahasiswi. $^{1}$

$$
\text { Mahasiswi tergolong dalam }
$$

kelompok usia peralihan dari masa remaja menjadi dewasa. Pola makan pada masa

peralihan tersebut terkadang tidak diperhatikan, sehingga tidak sedikit yang mengalami gangguan kesehatan, salah satunya adalah anemia. Anemia pada mahasiswi atau remaja putri seringkali disepelekan, sementara itu kelompok umur remaja putri beresiko untuk menderita anemia. Hal ini dapat disebabkan karena pada priode tersebut terjadi pertumbuhan pesat kedua setelah priode bayi, serta terjadinya menstruasi. ${ }^{2}$ Secara nasional prevalensi anemia gizi pada kelompok usia remaja (15-24 tahun) yaitu sebesar 18,4\%. ${ }^{1}$

Selain itu penyebab utama anemia pada remaja putri adalah kurangnya asupan zat gizi melalui makanan. Sebagian besar remaja putri lebih banyak mengkonsumsi makanan nabati yang kandungan zat besi sedikit, dibanding dengan makanan hewani, sehingga kebutuhan zat besi tidak terpenuhi. Peningkatan kebutuhan akan zat besi $(\mathrm{Fe})$ untuk pembentukan sel darah merah yang lazim terjadi pada masa pertumbuhan dan masa pubertas, dimana harus menjalani menstruasi setiap bulannya. Kehilangan zat besi di atas rata-rata dapat terjadi pada remaja putri dengan pola haid yang lebih banyak dan waktunya lebih panjang. ${ }^{3}$

Hasil survey yang lakukan sebelumnya menyebutkan pada umumnya mahasiswi mempunyai kebiasaan makan yang kurang baik. Beberapa yang sering mengkonsumsi makanan dalam jumlah yang tidak seimbang dibandingkan dengan kebutuhannya karena takut gemuk. Selain itu tinggal sendiri atau indekost membuat mahasiswi lebih tidak terbiasa untuk sarapan, kurang mengkonsumsi sayur dan buahbuahan, dan lebih sering makan makanan instan atau makanan cepat saji. Pola makan mahasiswi yang indekost juga cenderung tidak teratur dan jauh dari ukuran sehat. Hal ini diakibatkan oleh beberapa faktor, seperti aktivitas yang padat, kesulitan dari segi

ekonomi, kurangnya kepedulian dan pengetahuan akan pola makan yang baik.

Oleh karena itu pola makan mahasiswi menjadi fokus utama peneliti. Dimana subjek penelitian adalah mahasiswi Fakultas Ilmu Kesehatan, Universitas Muhammadiyah Parepare. Sebagai calon tenaga kesehatan mereka harus memiliki pola makan yang baik, agar dapat memotivasi 
masyarakat dalam promosi kesehatan untuk berpola makan yang baik, sesuai dengan pengetahuan yang mereka miliki. Selain itu status gizi yang baik juga merupakan bekal

mereka sebelum menikah, sehingga menghasilkan generasi bangsa yang bergizi. Penelitian ini bertujuan menganalisis pengaruh pola makan terhadap kejadian anemia pada mahasiswi yang tinggal di koskosan.

\section{BAHAN DAN METODE}

Penelitian ini akan dilakukan di Univeristas Muhammadiya Parepare, Kota Parepare, Provinsi Sulawesi Selatan. Populasi pada penelitian ini adalah seluruh mahasiswi Program Studi Kesehatan Masyarakat Fakultas Ilmu Kesehatan Universitas Muhammadiyah Parepare yang aktif kuliah di kampus yaitu angkatan tahun 2014-2016. Jumlah populasi dalam penelitian ini yaitu sebanyak 265 Orang. Sampel yang akan terlibat dalam penelitian ini berdasarkan hasil perhitungan adalah sebanyak 100 orang yang akan diambil secara purposive sampling. Kriteria sampel penelitian yaitu mahasiswi yang tinggal di kostan dan bersedia menjadi responden.

Instrument yang akan digunakan pada penelitian ini adalah formulir wawancara digunakan untuk mengetahui karakteristik dan pengetahuan responden. Formulir food frequency digunakan untuk mencatat jenis dan jumlah makanan yang dikonsumsi mahasiswi dalam ukuran rumah tangga dan ukuran berat dalam gram. Alat pengukur berat badan, yaitu timbangan standar dengan ketelitian 0,1 gram. Alat pengukur tinggi badan menggunakan microtoise yang memiliki ketelitian $0,1 \mathrm{~cm}$. Alat pemeriksaan kadar hemoglobin yang menggunakan metode cyanmethemoglobin. Penelitian ini menggunakan metode penelitian kuantitatif dengan rancangan cross sectional study. Variabel pada penelitian ini adalah umur, pola makan dan status anemia. Metode analisis yang digunakan adalah analisis deskriptif untuk univaribel, analisis uji chi square untuk analisis bivariabel dengan tingkat kemaknaan $p<0,05$.

\section{HASIL}

Hasil uji analisis univariabel ditunjukkan pada Tabel 1, yang menyatakan bahwa dari 100 orang responden sebagian besar responden berumur 19 tahun yaitu sebanyak 42 orang $(42 \%)$ dan berumur 20 tahun yaitu sebanyak 26 orang (26\%). Hasil penelitian menunjukkan bahwa sebagian besar responden sudah mencukupi Pola Makan atas Angka Kecukupan Gizi (AKG) yang telah ditentukan sebelumnya yaitu sebanyak 83 orang dan hanya 17 orang yang tidak mencukupi pola makannya atau AKG. 100 orang responden yang diteliti dan diperiksa kadar hemoglobinnya diperoleh data, bahwa sebanyak 39 orang yang mengalami anemia dan 61 orang yang tidak mengalami anemia.

Hasil uji bivariabel yang ditunjukkan pada Ttabel 2, yaitu antara pola makan 
dengan kejadian anemia, diketahui sebanyak 11 orang yang tidak mencukupi pola makannya dan mengalami anemia, sebanyak 6 orang yang tidak mencukupi pola makannya tetapi tidak mengalami anemia, selain itu sebanyak 28 orang yang mencukupi pola makannya tetapi mengalami anemia, sedangkan sebanyak 55 orang yang mencukupi pola makannya dan tidak mengalami anemia. Setelah diuji dengan menggunakan uji chi-square diperoleh hasil OR sebesar 1,206 dengan nilai $p$ value sebsar 0,018 . Hasil ini dapat disimpulkan bahwa ada pengaruh pola makan dengan kejadian anemia pada mahasiswi Fikes UMPAR. Kemudian dari hasil analisis diperoleh OR sebesar 1,206 artinya responden yang mempunyai pola makan tidak cukup cenderung 1,206 kali lebih besar mengalami anemia dibandingkan responden yang mempunyai pola makan cukup.

\section{PEMBAHASAN}

Mahasiswi merupakan kelompok umur remaja yang membutuhkan pola makan yang sehat dan seimbang. Pola makan yang baik sangat penting untuk semua orang, terutama untuk pertumbuhan remaja. Sayangnya banyak remaja memiliki pola makan yang tidak seimbang. Aktivitas mahasiswi yang begitu padat terkadang tidak lagi memperhatikan asupan makanan yang dikonsumsi. Untuk menjalankan aktivitas sehari-hari dibutuhkan pola makan yang seimbang, agar pasokan energi sesuai dengan keluaran energi.

Pada penelitian ini memaparkan bahwa pola makan responden yang dinilai berdasarkan AKG, telah mencukupi yaitu sebanyak $83 \%$, walaupun ada $17 \%$ yang tidak mencukupi pola makannya. Penelitian ini tidak sejalan dengan penelitian yang menyebutkan bahwa 91,0\% mahasiswa memiliki pola pada kategori kurang baik. Hal tersebut terjadi karena jenis sarapan, waktu sarapan, tingkat kecukupan energi dan zat dari sarapan mahasiswa kurang dari kebutuhan yang dibutuhkan ${ }^{4}$. Sedangkan pada penelitian ini responden yang tidak cukup pola makannya diakibatkan karena tidak sempat sarapan, lalu pada siang hari makan seadanya, selanjutnya makan malam dalam keadaan yang terlalu lelah untuk menyiapkan makanan sehat, maka solusi termudah dan tercepat adalah jajan. Diketahui bahwa jika makan diluar atau jajan gizinya tidak dapat dikontrol oleh pembeli.

Remaja putri dalam hal ini mahasiswi merupakan kelompok yang rawat menderita anemia. Anemia pada mahasiswi akan berdampak pada penurunan konsentrasi belajar, penurunan kesegaran jasmani dan gangguan pertumbuhan hingga perubahan siklus menstruasi. Beberapa faktor yang dapat menyebabkan terjadinya anemia antara lain yaitu perdarahan karena haid, penyakit infeksi, penyakit kronik, aktifitas fisik dan 
paling umum adalah karena ketidakcukupan asupan zat besi di dalam tubuh. ${ }^{5}$

Hasil penelitian tentang kejadian anemia pada mahasiswi menunjukkan bahwa sebagian besar responden tidak mengalami anemia yaitu sebanyak $61 \%$ dan ada 39\% yang mengalami anemia. Responden yang mengalami anemia disebabkan karena kurang mengkonsumsi protein, suka mengkonsumsi fast food dan junk food, serta sering mengkonsumsi minuman teh kemasan. Hasil penelitian ini sependapat dengan penelitian lain yang memaparkan bahwa anemia pada remaja putri disebabkan karena pola makan yang tidak teratur, pantang makan telor/daging/ikan, tidak suka mengkonsumsi sayur, kebiasaan makan fast food dan junk food. ${ }^{6}$

Hasil penelitian menunjukkan bahwa terdapat pengaruh antara pola makan dengan kejadian anemia pada mahasiswi $(\mathrm{p}<0.05)$. Responden yang mempunyai pola makan tidak cukup cenderung 1,206 kali lebih besar mengalami anemia dibandingkan responden yang mempunyai pola makan cukup. Hasil penelitian ini sejalan dengan penelitian yang dilakukan pada remaja putri di MTsN 02 Kota Bengkulu, menyatakan bahwa remaja putri yang memiliki pola makan yang tidak baik berisiko 1.2 kali untuk menderita anemia, dibanding dengan remaja putri yang berpola makan yang teratur dan baik. 78

Pola makan berpengaruh terhadap kejadian anemia karena banyak mahasiswi yang tidak teratur pola makannya, kurang mengkonsumsi protein, suka mengkonsumsi fast food dan junk food, sering mengkonsumsi minuman teh kemasan, serta aktifitas kampus yang padat sehingga membuat mereka sulit untuk menyiapkan makanan yang bergizi. Diketahui bersama bahwa pada umumnya remaja putri memiliki karakteristik kebiasaan makan tidak sehat. Antara lain kebiasaan tidak makan pagi, malas minum air putih, diet

tidak sehat karena ingin langsing (mengabaikan sumber protein, karbohidrat, vitamin dan mineral), kebiasaan mengemil makanan rendah gizi dan makanan siap saji. Sehingga remaja tidak mampu memenuhi keanekaragaman zat makanan yang dibutuhkan oleh tubuhnya untuk proses sintesis pembentukan hemoglobin $(\mathrm{Hb}){ }^{8}$

Faktor lain yang dapat menyebabkan pola makan mahasiswa adalah waktu makan siang yang sangat terbatas, jadwal kuliah yang padat dan jam kuliah kosong karena dosen tidak datang. Selain itu tinggal di indekost juga berpengaruh karena mereka harus mempersiapkan makan sendiri, terlambat makan atau diluar jadwal kebiasaan karena

waktu yang terbatas, dan harus memperhitungkan uang yang mereka punya. Pilihan lainnya adalah membeli makanan di warung atau penjaja makanan. ${ }^{9}$

Faktor gizi merupakan salah satu penyebab kejadian anemia. Faktor gizi terkait dengan defisiensi protein, vitamin dan mineral. Protein berperan dalam proses 
pembentukan hemoglobin, dalam jangka waktu lama tubuh kekurangan protein menyebabkan terganggunya pembentukan sel darah merah, sehingga menyebabkan timbulnya gejala anemia. 10

Kurangnya mengkonsumsi protein dapat menyebabkan terjadinya anemia. Sumber protein hewani merupakan sumber zat besi heme. Heme lebih mudah penyerapan dibanding dengan non heme. ${ }^{8}$ Zat yang dapat menghambat penyerapan besi atau inhibitor antara lain adalah kafein, tanin, oksalat, fitat yang terdapat dalam produk-produk kacang kedelai, teh dan kopi. ${ }^{10}$ Seperti halnya pada penelitian ini yang memaparkan bahwa banyak mahasiswi suka mengkonsumsi minuman teh kemasan. Teh merupakan minuman yang mengandung tanin yang dapat menurunkan penyerapan besi non heme dengan membentuk ikatan komplek yang tidak dapat diserap. ${ }^{10}$ Konsumsi 1 cangkir teh sehari dapat menurunkan absorbsi $\mathrm{Fe}$ sebanyak $49 \%$ pada penderita anemia defisiensi besi, sedangkan mengkonsumsi 2 cangkir teh sehari menurunkan absorbsi $\mathrm{Fe}$ sebesar $67 \%$ pada penderita anemia defisiensi Fe dan $66 \%$ pada kelompok kontrol. Teh yang dikonsumsi setelah makan hingga 1 jam akan mengurangi daya serap sel darah merah terhadap zat besi sebesar $64 \%$. ${ }^{11}$

\section{KESIMPULAN DAN SARAN}

Prevalensi anemia pada mahasiswi Fikes UM Parepare sebesar 39\% dan pola makan yang tidak mencukupi sebesar $17 \%$.
Terdapat pengaruh pola makan dengan kejadian anemia pada mahasiswi $\mathrm{p}$ value 0,018 dan responden yang mempunyai pola makan tidak cukup cenderung 1,206 kali lebih besar mengalami anemia dibandingkan responden yang mempunyai pola makan cukup.

Mengingat masih tingginya prevalensi anemia pada mahasiswi Fikes UM Parepare, diharapkan untuk merubah pola makan yang baik dan teratur dengan mengkonsumsi makanan yang mengandung protein baik nabati maupun hewani. Selain itu mengurangi mengkonsumsi junk food dan fast food, serta mengurangi mengkonsumsi teh kemasan.

\section{UCAPAN TERIMA KASIH}

Ucapan terima kasih penulis kepada mahasiswi Fikes UM parepare yang mau berpartisipasi dalam penelitian ini. Terima kasih juga kami ucapkan kepada Pimpinan dan Dosen, serta staff Fikes UM Parepare yang memberikan dukungan atas penelitian ini. Penulis juga mengucapkan terima kasih kepada semua pihak yang tidak dapat dituliskan satu per satu atas dukungan dan masukannya atas pelaksanaan penelitian ini.

\section{DAFTAR PUSTAKA}

1. Kemenkes RI. Riset Kesehatan Dasar (RISKESDAS) 2013. Lap Nas 2013. 2013:1-384. doi:1 Desember 2013.

\section{Brown JE. Nutrition Through the Life} Cycle. Cengage Learning; 2016. 
3. Arisman. Buku Ajar Ilmu Gizi: Gizi

Dalam Daur Kehidupan. Jakarta: EGC; 2008.

4. Miko A, Dina B, Gizi J, et al. HUBUNGAN POLA MAKAN PAGI DENGAN STATUS GIZI PADA MAHASISWI POLTEKKES

KEMENKES ACEH (Relationship

breakfast pattern with nutrition status at college student Polytechnic of Health, Ministry of Health, Aceh). Hub Pola Makan dengan Status Gizi Mahasiswa. 83 AcTion J. 2016.

5. Masthalina H, Laraeni Y, Dahlia YP. Pola konsumsi (faktor inhibitor dan enhancer $\mathrm{Fe})$ terhadap status anemia remaja putri. $J$ Kesehat Masy. 2015. doi:ISSN 1858-1196

6. Mariana W, Khafidhoh N. Hubungan Status Gizi dengan Kejadian Anemia pada Remaja Putri di SMK Swadaya Wilayah Kerja Puskesmas Karangdoro Kota Semarang Tahun 2013. J Kebidanan. 2013;2(4):35-42.

7. Putri RD, Simanjuntak BY, Kusdalinah. Hubungan Pengetahuan Gizi, Pola Makan dan Kepatuhan Konsumsi Tablet $\mathrm{Fe}$ dengan Kejadian Anemia Pada Remaja Putri. J Kesehat. 2017;VIII(3):400-405.

8. Suryani D, Hafiani R, Junita R. Analisis Pola Makan dan Anemia Gizi Besi Pada Remaja Putri Kota Bengkulu. J Kesehat Masy Andalas. 2015;10:11-18.

9. Surjadi C. Globalisasi dan Pola Makan Mahasiswa, Studi Kasus di Jakarta. J

Kesehat. 2013;4(6):416. http://www.kalbemed.com/portals/6/07_2 05Globalisasi dan Pola Makan Mahasiswa-Studi Kasus di Jakarta.pdf.

10. Masthalina H, Laraeni Y, Putri Y, et al. Pola Konsumsi (Faktor Inhibitor Dan Enhancer Fe) Terhadap Status Anemia Remaja Putri. Kemas. 2015;11(1):80-86. http://journal.unnes.ac.id/nju/index.php/ke mas\%0Ahttp://dx.doi.org/10.15294/.

11. Thankachan P, Walczyk T, Muthayya S, Kurpad A V., Hurrell RF. Iron absorption in young Indian women: The interaction of iron status with the influence of tea and ascorbic acid1-3. Am J Clin Nutr. 2008;87(4):881-886. doi:87/4/881 [pii] 


\section{$\underline{\text { LAMPIRAN }}$}

Tabel 1 Distribusi Variabel Dependen

\begin{tabular}{|c|c|c|}
\hline Variabel & Frekuensi & Presentase (\%) \\
\hline- Umur (Tahun) & 3 & 3 \\
\hline 18 & 42 & 42 \\
\hline 19 & 26 & 26 \\
\hline 20 & 12 & 12 \\
\hline 21 & 13 & 13 \\
\hline 22 & 3 & 3 \\
\hline 23 & 1 & 1 \\
\hline 24 & & 39 \\
\hline Kejadian Anemia & 39 & 61 \\
\hline Anemia & 61 & 17 \\
\hline Tidak Anemia & & 83 \\
\hline Pola Makan (AKG) & 17 & \\
\hline Tidak Cukup & 83 & \\
\hline Cukup & & \\
\hline
\end{tabular}

Tabel 2 Pengaruh pola Makan Terhadap Kejadian Anemia

\begin{tabular}{|c|c|c|c|c|}
\hline \multirow{2}{*}{ Pola Makan (AKG) } & \multicolumn{2}{|c|}{ Kejadian Anemia } & \multirow{2}{*}{ OR } & \\
\cline { 2 - 3 } & Anemia & Tidak Anemia & & \\
\hline Tidak Cukup & 11 & 6 & \multirow{2}{*}{0.018} & \multirow{2}{*}{1.206} \\
\hline Cukup & 28 & 55 & \\
\hline
\end{tabular}

